\title{
Blood concentrations of pancreatitis associated protein in neonates: relevance to neonatal screening for cystic fibrosis
}

\begin{abstract}
Jacques Sarles, Sandrine Barthellemy, Claude Férec, Juan Iovanna, Michel Roussey, Jean-Pierre Farriaux, Annick Toutain, Jacques Berthelot, Nicole Maurin, Jean-Pierre Codet, Patrice Berthézène, Jean-Charles Dagorn
\end{abstract}

INSERM U.315

Marseille, France

J Sarles

S Barthellemy

J Iovanna

P Bethézène

J-C Dagorn

Centre de

Biogénétique, CDTS

Brest

C Férec

Service de Médecine Nucléaire, CHU Brest J-P Codet

Centres de Dépistage Régionaux of Bretagne, Rennes M Roussey

Centre, Tours A Toutain

Nord-Pas de Calais, Lille

J-P Farriaux

Pays de Loire, Angers J Berthelot

Provence-Alpes-Côte d'Azur, Marseille

N Maurin

J Sarles

Correspondence to:

Dr J-C Dagorn

U.315 INSERM

46 Boulevard de la Gaye

13258 Marseille Cedex 09

France.

Email:

dagorn@marseille.inserm.f

Accepted 26 October 1998

\begin{abstract}
Aim-To determine whether pancreatitis associated protein (PAP) is a marker for cystic fibrosis which could be used in neonatal screening for the disease.

Methods-PAP was assayed on screening cards from 202807 neonates. Babies with PAP $\geqslant 15 \mathrm{ng} / \mathrm{ml}$, or $\geqslant 11.5 \mathrm{ng} / \mathrm{ml}$ and immunoreactive trypsinogen (IRT) $\geqslant 700$ $\mathbf{n g} / \mathrm{ml}$ were recalled for clinical examination, sweat testing, and cystic fibrosis transmembrane regulator (CFTR) gene analysis.

Results-Median PAP value was $2.8 \mathrm{ng} / \mathrm{ml}$. Forty four cases of cystic fibrosis were recorded. Recalled neonates $(n=398)$ included only 11 carriers. A receiver operating characteristic curve analysis showed that PAP above $8.0 \mathrm{ng} / \mathrm{ml}$ would select $0.76 \%$ of babies, including all those with cystic fibrosis, except for one with meconium ileus and two with mild CFTR mutations. Screening 27146 babies with both PAP and IRT showed that only $0.12 \%$ had PAP $>8.0 \mathrm{ng} / \mathrm{ml}$ and IRT $>700 \mathrm{ng} / \mathrm{ml}$, including all cases of cystic fibrosis. Conclusion-PAP is increased in most neonates with cystic fibrosis and could be used for CF screening. Its combination with IRT looks promising.
\end{abstract}

(Arch Dis Child Fetal Neonatal Ed 1999;80:F118-F122)

Keywords: cystic fibrosis; screening; pancreatitis associated protein

Cystic fibrosis (CF) is one of the most common autosomal recessive genetic disorders in Caucasian populations. ${ }^{1}$ It is caused by a mutation in the cystic fibrosis transmembrane regulator (CFTR) gene. ${ }^{2}$ In the absence of effective treatment, neonatal screening for it is restricted to a few countries. ${ }^{3}$ However, Farrell $e t a l^{4}$ recently showed that early diagnosis by screening was beneficial so that interest in it is likely to increase. ${ }^{5}$ The current standard screening test, the immunoreactive trypsinogen (IRT) assay, has improved since its first description by Crossley et al in $1979,{ }^{6}$ but its false positive rate of up to $1 \%$ remains a matter of concern. ${ }^{3} 7$

The rationale for IRT testing is that duct obstructions by protein plugs develop in utero in the CF pancreas, ${ }^{8}$ leading to enzyme leakage into the blood. However, transient obstruction of the ducts of an otherwise healthy pancreas could also lead to increased blood IRT, so reducing the specificity of screening. One solu- tion would be to couple IRT with detection of $\triangle F 508$, the most common CFTR mutation in Caucasians. ${ }^{9}$ This strategy is used in several countries, but has the drawback of unwanted carrier detection. ${ }^{10}{ }^{11}$ In addition, it might not be applicable for populations in whom the mutation is less prevalent. ${ }^{12}$ Finally, it is irrelevant in countries where informed consent is required by law before any DNA testing.

Studies on acute pancreatitis led us to consider using the blood concentration of pancreatitis associated protein (PAP) for CF screening. PAP is a secretory protein that is absent from the healthy pancreas and synthesized in high amounts after sustained pancreatic stress. ${ }^{13}$ Thus PAP may already be synthesized in utero in the CF pancreas and present in blood at birth. A pilot retrospective study ${ }^{14}$ showed that IRT negative and most non-CF IRT positive neonates had normal PAP, whereas PAP was increased in neonates with CF.

We report here the results of PAP testing of 202807 neonates. The aim of this prospective multicentre study was to establish the distribution of PAP values in neonates, to define the range of PAP values in CF, and to assess the relevance of PAP testing for neonatal screening for $\mathrm{CF}$.

\section{Methods}

Screening cards collected at day 3 for detection of phenylketonuria and hypothyroidism were provided by the screening centres from five regions of France. Studies conducted in France to evaluate CF screening using IRT showed that the incidence varied from 1 in 3200 to 1 in 4900. ${ }^{15}$ Assuming that the incidence in the regions participating in our study would be 1 in 4000 , we calculated that a cohort size of 200000 babies would include, with $95 \%$ confidence intervals, 38 to $62 \mathrm{CF}$ babies.

Informed consent was obtained from the parents concerned before inclusion in the study.

A total of 215437 screening cards were received over 14 months, corresponding to all neonates born during that period except for 72 whose parents refused inclusion. Among these cards, $12630(5.9 \%)$ were excluded because the blood sample remaining after the other screening tests were done was inadequate. Analysis was finally conducted on 202807 neonates. Cards were coded before processing. We recalled all babies with PAP $\geqslant 15 \mathrm{ng} / \mathrm{ml}$ and also those with PAP between $11.5 \mathrm{ng} / \mathrm{ml}$ 
and $15 \mathrm{ng} / \mathrm{ml}$ if they had an IRT $\geqslant 700 \mathrm{ng} / \mathrm{ml}$. A preliminary study had shown that these criteria would select a number of babies compatible with the handling capacities of the screening centres (less than $0.5 \%$ of the population). Recalled neonates underwent clinical examination, sweat testing, IRT assay (RIAGnost Trypsin neonatal, CIS Bio international, Gif-sur-Yvette, France), and CFTR mutation analysis after written informed consent had been obtained from the parents. Paediatricians from the regions involved were informed of the study to ensure that all infants suspected of having CF were immediately reported to the screening centres.

One screening centre (Rennes, $\mathrm{n}=27$ 146) conducting $\mathrm{CF}$ screening on a routine basis using IRT (RIA-Gnost Trypsin neonatal, threshold $700 \mathrm{ng} / \mathrm{ml}$ ) made those data available to us.

The protocol was approved by the Association Française pour le Dépistage et la Prévention des Handicaps de l'Enfant and the Commission Nationale Informatique et Libertés. Cards were received by mail from each centre twice a week and processed within five days. PAP was assayed in eluates of discs ( $\varnothing 4 \mathrm{~mm}$ ), using a commercial ELISA (PancrePAP, DYNABIO SA, La Gaude, France) with pure PAP as standard. The discs were eluted in $150 \mu$ phosphate buffered saline overnight at $4^{\circ} \mathrm{C}$. Assays were performed on $80 \mu 1$ of the eluates, according to the manufacturer's recommendations. Briefly, the antigen was captured on specific IgG immobilised on the plates. Colour development was achieved by incubation with biotinylated antibodies and addition of avidinperoxidase complex and 3-3'-5-5' tetramethylbenzidine as chromogenic substrate. Optical density of the reaction mixture was read at 492 $\mathrm{nm}$. Assays were performed on a DIAS Immunoassay automated system (Dynatech Laboratories, Guyancourt France). Reproducibility of the assay on serum samples was $\pm 5 \%$. In card eluates it was generally within $\pm 10 \%$, when the filling of the cards was adequate. PAP values above $11.5 \mathrm{ng} / \mathrm{ml}$ were checked by duplicating the assay, and decision for recall was based on the average value. PAP value obtained from a given card remained stable within two months of the sample being taken, and then decreased progressively.

DNA was extracted from white cells collected from screening cards. Samples were amplified by 40 cycles of PCR, as described before. ${ }^{16}$ Amplification products were analysed by denaturing gradient gel electrophoresis. Sequence of the amplification primers and conditions for optimal denaturing gradient gel electrophoresis (DGGE) of the corresponding amplification products have been described before. ${ }^{16}$ DNA sequencing was performed on single stranded DNA obtained by asymmetric PCR.

We screened recalled neonates for mutations in exons 10 and 11 of the CFTR gene. This covered $75 \%$ of CFTR mutations in the French population. When only one mutation was identified, further analysis was conducted on exons $4,7,19,20$, and 21 , leading to a cov-

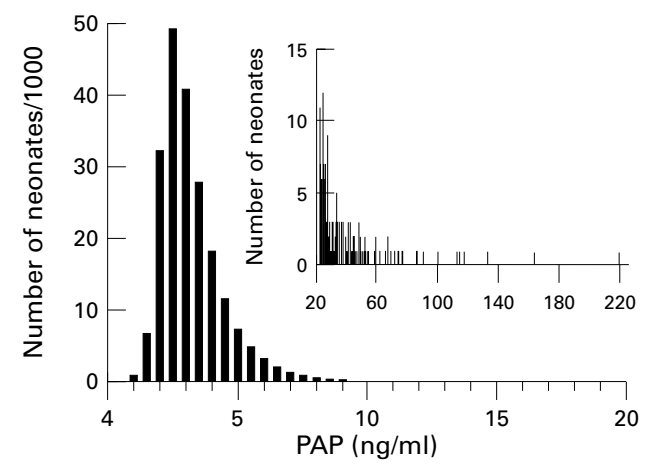

Figure 1 Distribution of blood PAP concentrations in 202807 neonates. PAP concentrations were divided into successive classes of $0.5 \mathrm{ng} / \mathrm{ml}$; columns represent number of neonates in each class; insert shows distribution of PAP values above $20 \mathrm{ng} / \mathrm{ml}$.

erage of $95 \%$ of the mutations identified in that population. In neonates with $\mathrm{CF}$, analysis was extended to other exons when necessary.

\section{Results}

Distribution of PAP values in the 202807 neonates is shown in fig 1 . Lowest values were close to background whereas highest values reached $220 \mathrm{ng} / \mathrm{ml}$. The median value was 2.8 $\mathrm{ng} / \mathrm{ml}$. The value of the 99 th percentile was 7.6 $\mathrm{ng} / \mathrm{ml}$.

A total of 433 neonates $(0.21 \%$ of the whole population) were recalled for further examination, of whom 21 were lost to follow up due to early death $(n=11)$, parental refusal $(n=9)$, or the wrong address $(n=1)$. Clinical information, sweat test value, and CFTR gene analysis were obtained in $379(87.3 \%), 261$ (60\%), and 386 (89\%) babies, respectively, with at least two results available for 392 babies (91\%). Among the 54 neonates for whom clinical information was absent, CF diagnosis was ruled out in 39 by sweat testing $(n=21)$ and genetic analysis $(n=34)$. None of the three parameters was available in 15 babies, nine of whom were tested for IRT, which was high in four.

Thirty four recalled babies were diagnosed with CF. One had meconium ileus. Among the 398 non-CF babies, 11 were heterozygous for a CFTR mutation. A third of the babies $(\mathrm{n}=$ 135) were apparently healthy. Most of the other

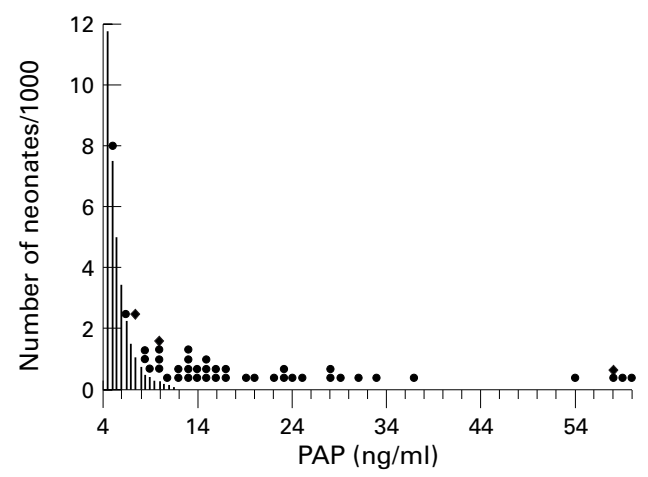

Figure 2 PAP concentrations in neonates with $C F$ Histogram represents distribution of PAP concentrations in the population in the range 4-60 $\mathrm{ng} / \mathrm{ml}$. All 44 neonates had PAP concentrations in that range, except for one with PAP at $72 \mathrm{ng} / \mathrm{ml}$, indicated at $60 \mathrm{ng} / \mathrm{ml}$. Diamonds correspond to babies with $C F$ and meconium ileus. 


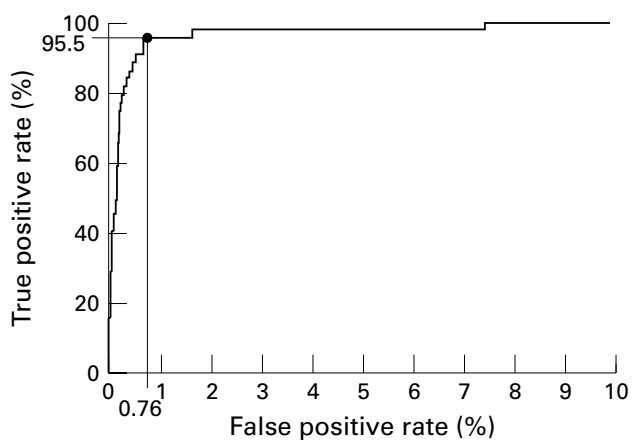

Figure 3 ROC analysis of PAP in CF screening. The point corresponding to $P A P=8.0 \mathrm{ng} / \mathrm{ml}$ is indicated, with a true positive rate at $95.5 \%$ and a false positive rate at $0.76 \%$.

two thirds $(n=263)$ were inpatients. The most frequent indications were prematurity $(35 \%)$, gastrointestinal tract abnormalities (15\%), including Hirschsprung's disease, intestinal obstruction and necrotising enterocolitis, infections $(6 \%)$ and intrauterine growth retardation. Only five cases of chromosomal abnormality were reported.

Forty four babies with CF were diagnosed during the study ( 1 in 4600 ). PAP values ranged from 4.9 to $72 \mathrm{ng} / \mathrm{ml}$, median 15.5 $\mathrm{ng} / \mathrm{ml}$ (fig 2). The 34 cases with $\mathrm{PAP} \geqslant 11.5$ $\mathrm{ng} / \mathrm{ml}$ are described above. Of the 10 other cases, nine were diagnosed because of clinical symptoms, including two diagnosed at birth because of meconium ileus. The tenth, screened for raised IRT in the Rennes programme, was asymptomatic with a negative sweat test but showed two CFTR mutations $(\Delta \mathrm{F} 508 / \mathrm{R} 117 \mathrm{H})$.

The CFTR genotype was investigated in all infants. The $\Delta \mathrm{F} 508 / \Delta \mathrm{F} 508$ genotype was present in $58 \%$ of them. Other genotypes were $\Delta \mathrm{F} 508 / \mathrm{G} 542 \mathrm{X}(\mathrm{n}=4), \Delta \mathrm{F} 508 / \mathrm{N} 1303 \mathrm{~K}$ $(\mathrm{n}=2), \Delta \mathrm{F} 508 / \mathrm{I} 148 \mathrm{~T}(\mathrm{n}=2), \Delta \mathrm{F} 508 / \mathrm{R} 117 \mathrm{H}$, $\Delta \mathrm{F} 508 / \mathrm{R} 553 \mathrm{X}, \Delta \mathrm{F} 508 / 1717-1 \mathrm{G}->\mathrm{A}, \Delta \mathrm{F} 508 /$ 1078delT, $\quad \Delta \mathrm{F} 508 / 2789+5 \mathrm{G}->\mathrm{A}, \quad \Delta \mathrm{F} 508 /$ E1308X (a novel CFTR mutation), R553X/ 394delTT, and N1303K/R553X. Two genotypes remain to be completed $(\Delta \mathrm{F} 508 / \mathrm{N}$, G553X/N). All CF neonates had high IRT values. All also had a positive sweat test, except for the baby with a $\Delta \mathrm{F} 508 / \mathrm{R} 117 \mathrm{H}$ genotype

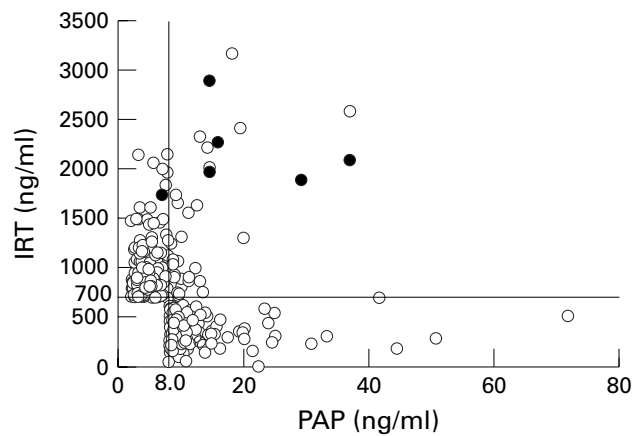

Figure 4 Correlation between IRT and PAP concentrations in 27146 neonates from Rennes. Each PAP value is plotted against the corresponding IRT value. The putative PAP threshold at $8.0 \mathrm{ng} / \mathrm{ml}$ selected from the ROC curve (fig 3) and cutoff value used in that region (700 $n \mathrm{~g} / \mathrm{ml}$ ) are indicated. Neonates with $\mathrm{CF}$ are indicated by closed circles. Values from neonates with $P A P<8.0 \mathrm{ng} / \mathrm{ml}$ and IRT $700 \mathrm{ng} / \mathrm{ml}(\mathrm{n}=26 \mathrm{603})$ were not plotted.

\section{Key messages}

- $\mathrm{CF}$ neonatal screening with PAP is technically feasible in the same environment as other neonatal screenings (PKU, hypothyroidism)

- CF neonatal screening with PAP alone performs similarly to screening with IRT alone, with less carrier detection

- Combining PAP with IRT for CF neonatal screening could be as efficient as the IRT/DNA strategy, but would be cheaper and incur limited carrier detection

- If a legal requirement for informed consent before DNA testing has expired, the PAP/IRT strategy would be an alternative to the IRT/DNA strategy

(PAP $=6.8 \mathrm{ng} / \mathrm{ml})$, who remains asymptomatic after 24 months. This baby has a $7 \mathrm{~T} / 9 \mathrm{~T}$ polymorphism on intron 8 of the CFTR gene. Because the $9 \mathrm{~T}$ is always associated with the $\Delta \mathrm{F} 508$ allele, the $\mathrm{R} 117 \mathrm{H}$ is associated with the $7 \mathrm{~T}$, which predicts absence of CF features. No correlation was observed between the genotypes and PAP concentrations, except for mutations predicting mild pancreatic damage. $\mathrm{CF}$ infants with meconium ileus $(\mathrm{n}=3)$ were excluded from analysis because their screening is irrelevant. ${ }^{3}{ }^{7} \mathrm{~A}$ receiver operating characteristic curve (ROC) $)^{17}$ was constructed with PAP increments of $0.5 \mathrm{ng} / \mathrm{ml}$ (fig 3). For each PAP value, the percentage of $\mathrm{CF}$ babies with PAP above that value $(100 \%=41)$ was plotted against the percentage of non-CF babies with PAP above the same value $(100 \%=202759)$. That representation allows estimation of various thresholds of PAP for CF screening, keeping in mind that additional CF babies can remain unreported and that PAP values under $11.5 \mathrm{ng} / \mathrm{ml}$ were not verified by duplicating the assay. The curve predicts that to detect all CF neonates, $8 \%$ would need to be recalled, which is clearly unacceptable. However, a PAP threshold of $8.0 \mathrm{ng} / \mathrm{ml}$, corresponding to an acceptable recall rate of $0.76 \%$, would have selected 39/41 CF neonates. The lowest CF value above that threshold was $8.5 \mathrm{ng} / \mathrm{ml}$. The two CF patients with PAP $<8.0 \mathrm{ng} / \mathrm{ml}$ had genotypes predicting a mild phenotype ${ }^{18}{ }^{19}$ : $\Delta \mathrm{F} 508 / \mathrm{R} 117 \mathrm{H}(\mathrm{PAP}=6.8 \mathrm{ng} / \mathrm{ml})$ and $\Delta \mathrm{F} 508 /$ $2789+5 \mathrm{G}->$ A $($ PAP $=4.9 \mathrm{ng} / \mathrm{ml})$.

IRT data for neonates from Rennes were obtained from the regional screening programme. The IRT cutoff for recall was 700 $\mathrm{ng} / \mathrm{ml}$, which selected 307 neonates $(1.13 \%)$. The putative PAP threshold at $8.0 \mathrm{ng} / \mathrm{ml}$ determined from the ROC curve (fig 3 ) would have selected 268 neonates (1.0\%). Fig 4 shows the plot of IRT against PAP. A linear correlation was obtained between IRT and PAP under $700 \mathrm{ng} / \mathrm{ml}$ and $8.0 \mathrm{ng} / \mathrm{ml}$, respectively. The equation of the curve was IRT = 22.7 PAP $+244\left(\mathrm{r}^{2}=0.041\right)$. Although significant, the correlation was small. For values above those thresholds, PAP and IRT were not correlated. Only 32 neonates $(0.12 \%)$ had a $\mathrm{PAP} \geqslant 8.0 \mathrm{ng} / \mathrm{ml}$ and an IRT $\geqslant 700 \mathrm{ng} / \mathrm{ml}$. 
That group included four heterozygotes and five CF neonates. The sixth was the asymptomatic baby (IRT $=1750 \mathrm{ng} / \mathrm{ml}$, PAP $=6.8 \mathrm{ng} / \mathrm{ml}, \Delta \mathrm{F} 508 / \mathrm{R} 117 \mathrm{H})$ described above.

\section{Discussion}

To evaluate the usefulness of the PAP assay in CF neonatal screening the distributions of PAP values in CF and non-CF babies from the same population needed to be compared. We designed a cohort study in which PAP was assayed in 202807 neonates, among whom 44 $\mathrm{CF}$ cases were detected. The incidence ( 1 in 4600) was in the expected range. ${ }^{7}$ PAP was significantly higher in $\mathrm{CF}$ than in non-CF babies, as expected from the observation that the CF pancreas is already damaged in utero. ${ }^{8}$ The two lowest PAP values in CF neonates (4.9 and $6.8 \mathrm{ng} / \mathrm{ml}$ ) corresponded to genotypes associated with mild pancreatic phenotype, ${ }^{18}{ }^{19}$ which corroborates the correlation between PAP expression and the severity of pancreatic damage. ${ }^{20}$ The third lowest value $(7.5 \mathrm{ng} / \mathrm{ml})$ corresponded to a baby with meconium ileus. We obtained a blood sample from that baby after the obstruction had resolved and PAP had increased to $22.1 \mathrm{ng} / \mathrm{ml}$ (day 10). Many babies with meconium ileus also have IRT values below the screening threshold. ${ }^{3}$ It is not known why measures of pancreatic dysfunction are abnormally low in some patients with the most serious neonatal forms of the disease. ROC analysis was conducted to evaluate the performances of PAP (fig 3). Hypotheses based on that analysis should take into account that the follow up of the cohort was 34 months for the first babies included and 20 months for the last ones. Therefore, some CF babies may remain unreported. Based on the present data, a threshold of $8.0 \mathrm{ng} / \mathrm{ml}$ would require recalling $0.76 \%$ of babies and would have detected $42 / 44 \mathrm{CF}$ patients, including three with meconium ileus diagnosed without screening. Among the three CF babies with PAP $<8.0 \mathrm{ng} / \mathrm{ml}$, one would have been diagnosed because he presented with a meconium ileus. The two other cases (PAP of 6.8 and $4.9 \mathrm{ng} / \mathrm{ml}$ ) underscore the limitations of PAP in screening. We expected children with mild phenotype to show lower PAP values because of limited pancreatic damage. We are concerned that we could miss those with pulmonary damage, albeit limited, but whether asymptomatic babies with a genotype predicting a mild pulmonary phenotype $(\Delta \mathrm{F} 508 / \mathrm{R} 117 \mathrm{H}$ and $9 \mathrm{~T} / 7 \mathrm{~T}, \mathrm{PAP}=6.8$ $\mathrm{ng} / \mathrm{ml}$ ) should be screened is questionable.

Comparison of the screening performances of PAP and IRT is difficult because data for IRT depend on the cutoff chosen, which affects sensitivity and specificity. In most programmes reporting a sensitivity above $95 \%$, the IRT cutoff generates about $1 \%$ false positive results, ${ }^{10} 11$ as observed in the Rennes programme. This falls within the range of the predicted specificity for PAP.

We obtained information on non-CF babies with raised PAP ( $\mathrm{n}=398$ )by selecting those with PAP $>15 \mathrm{ng} / \mathrm{ml}$ or PAP $>11.5 \mathrm{ng} / \mathrm{ml}$ and
IRT $>700 \mathrm{ng} / \mathrm{ml}(0.21 \%$ of the population). Among them, two thirds were inpatients at birth, suggesting that besides specific damage inherent in $\mathrm{CF}$, various conditions of stress can affect the pancreas and trigger PAP expression. The pancreas of babies heterozygous for a CFTR mutation seems unaffected, as the prevalence of carriers among babies with raised PAP was the same as that of the total population. Thus detection of an excessive number of heterozygotes, a common problem using IRT in current screening programmes, would not occur with PAP. ${ }^{10} 11$

Neonatal IRT values were available in a fraction of the population (Rennes, $\mathrm{n}=27$ 146). In that sample the IRT cutoff of 700 $\mathrm{ng} / \mathrm{ml}$ and the putative PAP threshold of 8.0 $\mathrm{ng} / \mathrm{ml}$ would have selected similar proportions of neonates $(1.13 \%$ and $1.0 \%$, respectively) suggesting that, in these conditions, PAP and IRT would have similar specificities. However, there was a lack of correlation between raised PAP and IRT. Thus, as observed in adults with pancreatic diseases, ${ }^{13}$ raised blood concentrations of PAP and pancreatic enzymes do not always reflect the same pathophysiology. Therefore, selecting babies with high PAP and IRT would increase the specificity of screening without altering sensitivity. In fact, only $0.12 \%$ of babies from Rennes had increased values for both of these variables, including all CF cases, except for the asymptomatic baby described above. This is in the range of the recall rates reported in IRT/DNA screening programmes. ${ }^{10} \mathrm{~A}$ further step in DNA testing of babies selected by PAP/IRT would have decreased the recall rate to $0.03 \%$ (5 CF and 4 heterozygotes) and the false positive rate to $0.015 \%$. Our results, although promising, were obtained in a small population and should be considered preliminary.

We concluded that high PAP values seen in most CF babies indicate that this test should be considered for CF screening. We could not thoroughly evaluate its performance because accurate assessment of the false negative rate would have required a much larger cohort, but it should be similar to that reported for IRT, with the advantage of limited carrier detection. In practice, the PAP ELISA is a reliable test which can be fully automated with standard hardware. Its cost (10 FF, £1.10, \$1.75) should decrease if produced on a larger scale. Finally, a two tier strategy involving PAP and IRT would restrict DNA analysis to a much smaller population. This would improve the performance and cost of CF neonatal screening and be an obvious advantage when informed consent is required before genetic testing.

The following investigators participated in the multicentre study: B Mercier, I Quéré, CDTS Brest, E Paux, Centre de Dépistage de Lille L Larget-Piet, Centre de Dépistage d'Angers. We thank P Ayyad and D Michel for technical assistance, and Gary Burkhart for revision of the manuscript.

This work was supported by grants from the Association Française de Lutte contre la Mucoviscidose, the Caisse Nationale d'Assurance Maladie des Travailleurs Salariés, the Programme Hospitalier de Recherche Clinique, and DYNABIO S.A. 
1 Welsh MJ, Tsui LC, Boat TF, Beaudet AL. Cystic Fibrosis. In: Scriver CF, Beaudet AL, Sly WS, et al, eds. The and York: MacGraw-Hill, 1995: 3799-876.

2 Kerem BS, Rommens JM, Buchanan JA, et al. Identification of the cystic fibrosis gene: genetic analysis. Science 1989;245:1073-80

3 Wilcken B. Newborn screening for cystic fibrosis: its evaluation and a review of the current situation. Screening 1993;2:43-62.

4 Farrell P, Kosorok MR, Laxova A, et al. Nutritional benefits of neonatal screening for cystic fibrosis. $N$ Engl $\mathcal{7} \mathrm{Med}$ 1997;337:963-9.

5 Dankert-Roelse JE, te Meerman GJ. Screening for cystic fibrosis. Time to change our position? (Editorial). $\mathrm{N} \mathrm{Engl} \mathcal{F}$ Med 1997;337:997-8

6 Crossley JR, Elliott RB, Smith PA. Dried blood spot screening for cystic fibrosis in the newborn. Lancet 1979;i:4724 .

7 Farriaux JP, Briard ML. Le dépistage néonatal de la mucoviscidose. Enjeux et résultats du programme français d'évaluation. F Immunol Anal Biol Spec 1992;33:71-5.

8 Boué A, Muller F, Nezelof C, et al. Prenatal diagnosis in 200 pregnancies with 1-in-4 risk of cystic fibrosis. Hum Genet 1986;74:288-97.

9 Seltzer WK, Accurso F, Fall MZ, et al. Screening for cystic fibrosis : feasibility of molecular genetic analysis of dried blood specimens. Biochem Med Metab Biol 1991;46:105-9.

10 Gregg RG, Simantel A, Farrell PM, et al. Newborn screening for cystic fibrosis in Wisconsin: comparison of biochemical and molecular methods Pediatrics 1997;99:819-24.
11 Wilcken B, Wiley V, Sherry G, Bayliss U. Neonatal screening for cystic fibrosis. A comparison of two strategies for case detection in 1.2 million babies. $\mathcal{f}$ Pediatr 1995;127:965-70

12 Worldwide survey of the delta F508 mutation. Report from the Cystic Fibrosis Genetic Analysis Consortium. Am $\mathcal{F}$ Hum Genet 1990;47:354-9.

13 Iovanna J, Keim V, Nordback I, et al. Serum levels of pancreatitis-associated protein as indicators of the course of acute pancreatitis. Gastroenterology 1994;106:728-34.

14 Iovanna J, Férec C, Sarles J, Dagorn JC. The PancreatitisAssociated Protein (PAP) A new candidate for neonatal screening of cystic fibrosis $C R$ Acad Sci 1994;317:561-4.

15 Farriaux JP, Dhondt JL. Données épidémiologiques. Dépistage néo- et anténatal de la mucoviscidose. Rev Pulm Clin 1995;51:109-14.

16 Audrézet MP, Mercier B, Guillermit H, et al. Identification of 12 novel mutations in the CFTR gene. Hum Mol Genet 1993;1:51-4.

17 Robertson EA, Zweig MH. Use of receiver operating characteristic curves to evaluate the clinical performances of analytical systems. Clin Chem 1981;27:1569-74.

18 Férec C, Verlingue C, Guillermit $\mathrm{H}$, et al. Genotype analysis of cystic fibrosis patients. Hum Mol Genet 1993;2:1557-60.

19 Fitzgerald D, Van Asperen P, Henry R, et al. Delayed diagnosis of cystic fibrosis in children with a rare genotype $(\Delta \mathrm{F} 508 / \mathrm{R} 117 \mathrm{H})$. F Pediatr Child Health 1995;31:168-71.

20 Keim V, Willemer S, Iovanna J, Adler G, Dagorn JC. Rat pancreatitis-associated protein is expressed in relation to the severity of experimental pancreatitis. Pancreas 1994;9:606-12. 